\title{
Exploring the Factors Influencing the Readiness of Faculty and Students on Online Teaching and Learning as an Alternative Delivery Mode for the New Normal
}

\author{
Eden C. Callo ${ }^{1}$, Alberto D. Yazon ${ }^{2, *}$ \\ ${ }^{1}$ Academic Affairs, Laguna State Polytechnic University, Philippines \\ ${ }^{2}$ Curriculum and Instruction Development, and Quality Assurance, Laguna State Polytechnic University, Philippines
}

Received April 29, 2020 ; Revised June 2, 2020; Accepted July 1, 2020

Copyright $\bigcirc 2020$ by authors, all rights reserved. Authors agree that this article remains permanently open access under the terms of the Creative Commons Attribution License 4.0 International License

\begin{abstract}
The Laguna State Polytechnic University (LSPU) joins the Philippine government with all its actions by launching an initiative to take care of its students and employees, and the academic community amid the spread of the COVID-19 disease. This descriptive-correlational study investigated the factors influencing the readiness in online teaching and learning as an alternative delivery mode to continue the teaching-learning process, even the absence of face-to-face interactions between teachers and students. The content-validated and researchers-made online survey instrument, which reported an excellent reliability index of Cronbach $\alpha=0.95$, was administered via a google form. Responses from 348 faculty and 7,205 students at the university were analyzed using descriptive statistics such as frequency count, percent, mean, and standard deviation. Multiple linear regression analysis was employed to determine the significant predictors of respondent readiness. The results revealed that respondent familiarity and capability, preparation, device and access connectivity, self-efficacy, and experience with technology significantly influence their readiness on the conduct of online teaching and learning modality. It is concluded that faculty and student readiness on online teaching and learning is determined by their competence, accessibility of ICT tool, preparedness, confidence in their ability to use technology, and exposure to e-learning materials. Hence, the university and in the broader scope, the Commission on Higher Education (CHEd), may conduct series of training for teachers as a capacity building to equip them with knowledge and competencies on the use of flexible or blended learning. Further, a university-wide learning system may be designed, adopted, and implemented in case the Enhanced Community Quarantine will not be lifted for a longer period.
\end{abstract}

Keywords Readiness on Online Teaching and Learning, Familiarity and Capability, Device Access and Connectivity, Preparedness, Self-efficacy, Experience with Technology

\section{Introduction}

In 2018, Shailendra, P., Prageet A., Parul G., Diptiranjan, M., Ratri, P., Rosner, R., \& Sindhi, S. presented the status and challenges and trends in the online education arena in five regions of the world - North America, Europe, South America, Asia, Asia-Pacific, and Africa. Australia and New Zealand have recognized online education to be a potent tool for peer and collaborative learning and, in a technologically rich context, are witnessing growing popularity of online education programs. Ghana, South Africa, and Malawi from African countries lead the online education movement in the continent with the support of government policies promoting online education. It is highlighted in their article that the universities of USA are facing the challenge of continuously declining enrollments in their education programs. India, a developing economy from Asia, formally experienced online education only in 2008. Recent research proves that country-level factors of India are providing impetus to the growth of online education in the country, and with the active participation of governments at all levels, this market is expected to record continuous growth in the coming years too. Middle East countries have been late followers of online education. Past research reveals that low internet penetration, low public esteem for online learning, and lack of online educational repositories in Arabic language are main obstacles to the growth of online education in Middle East countries. 
We are facing unprecedented challenges - social, economic, and environmental - driven by accelerating globalization and a faster rate of technological developments. At the same time, those forces are providing us with myriad new opportunities for human advancement (OECD, 2018). The dilemma in which higher education institutions are now facing is also unprecedented. The Higher Education Institutions (HEIs) are being caught in a pandemic caused by the Corona Virus Disease (COVID) 19. This pandemic is like a war that the HEIs are not prepared for how they will fight the enemy. Although the HEIs are being taught how to fight the battle and win the war, the art of warfare is as old as time. The present war has no soul, ha no mercy, and unidentified.

The implementation of the Enhanced Community Quarantine (ECQ) and the extension thereof is a national effort to curb the spread of this pandemic. Higher education institutions, including academics, university officials, government officials, and community partners, must work together to assure that what needs to happen does happen.

The current health crisis has prompted higher education institutions to assess the changing landscape of online teaching and learning in the Philippines. Naldoza (2020) from Philippine Normal University conducted an initial assessment regarding the preparedness of teachers for online teaching and learning. His study determined the perception of the use of the Learning Management System as a platform for delivering courses. Likewise, it pointed out issues on customization, teacher and students' preparedness, infrastructure constraints, as well as flexibility in teaching and learning.

On March 11, 2020, Emmanuel reported that "the Ateneo de Manila University decided to do a dry run of moving fully towards online education. This was to enable students to Learn from Home (LFH). At this time, the university was already preparing laptops and data USB sticks for loaning out to students and faculty that would need them. Data from the initial stage of the dry run started to come in from both the student council and various units around the university. Although a few students had issues, $90 \%$ of students rated the online learning above average. It is also observed that $90 \%$ of students were satisfied with their Internet connectivity. This shows that online learning satisfaction is likely directly proportional to satisfaction with Internet connectivity. Further, the initial data showed that around $12 \%$ of students had difficulty with Internet access and access to computing resources. This roughly reflects the reality of Internet connectivity in the country."

There have been several studies done that examined faculty and students' perception of their readiness to teach and learn online. The 2017 national survey of online learning in Canadian post-secondary education of Bates (2018) disclosed that the major benefit of online learning as perceived by respondents was that it results in greater access and more flexibility for students. It is also an avenue for innovative teaching. However, he noted that lack of adequate resources and specialist staff, lack of training, and resistance from instructors, were barriers or challenges to online learning.

Martin, Budhrani, and Wang (2019) measured faculty attitudes on the importance of online teaching competencies and the faculty's perception of their ability to confidently teach online. They asserted that studies of online teaching competencies are important, as they provide information about how online faculty might be trained and supported by professional development initiatives in higher education institutions. When online teaching professional development programs are designed, it is important to cover aspects of competencies, such as course design, course communication, technical, and time management, and specific attention should be given to competencies that faculty rated low in terms of importance and their perception of their own ability. The results of their study have implications for (1) faculty who are teaching online or getting prepared to teach online, (2) instructional designers who assist faculty in their preparation to teach online, and (3) administrators who can provide support for the faculty to prepare for online teaching. It is important for the faculty to be prepared in all four areas of online teaching: course design, course communication, time management, and technical.

In the study conducted by Gay (2016), results show that $72.6 \%$ were individually e-ready by having access to a dedicated network connection for substantial periods of time, routinely communicating with persons using electronic technologies, being self-motivated and independent learners, with a predisposition towards embracing and using new technologies. During the pre-course phase, online instructor e-readiness had a moderate impact on both technical (ELS quality and service quality) and non-technical (information quality) aspects of the ELS. During course delivery, its influence decreased with the technical aspect (ELS use) but increased with the non-technical aspect of the course (instructor satisfaction). At course completion, the main benefit was enhanced teaching skills, while a lack of contact with others was the main challenge.

The digital competence of faculty can be linked to their research productivity. According to the research of Yazon, Manaig, Buama, and Tesoro (2019), the increase in understanding, finding, using, and creating information using digital technologies is positively related to faculty members' ability to conduct, complete, present and publish a research article. Likewise, faculty member's digital competence is strong and significantly correlated to their research productivity, which clearly indicates that as their knowledge, skills, and attitudes for working, living and learning in the knowledge society increases, there is also a significant increase in their ability to produce publishable research outputs.

Students' readiness for e-learning application in Higher Education in Iran is explored by Rasouli, Rahbania, and 
Attaran (2016). They investigated if students are ready to participate in e-learning in aspects of collaborative communication skills, cognitive skills, and skills in working with computers and internet access, cognitive skills, and leadership skills.

Hung, Chou, Chen, and Own (2010) scrutinized learner readiness for online learning in Taiwan. Through confirmatory factor analysis, the Online Learning Readiness Scale (OLRS) was validated in five dimensions: self-directed learning, motivation for learning, computer/Internet self-efficacy, learner control, and online communication self-efficacy. Research data gathered from college students in five online courses revealed that students' levels of readiness were high in computer/Internet self-efficacy, motivation for learning, and online communication self-efficacy and were low in learner control and self-directed learning. This study found that gender made no statistical differences in the five OLRS dimensions, but that higher grade (junior and senior) students exhibited significantly greater readiness in the dimensions of self-directed learning, online communication self-efficacy, motivation for learning, and learner control than did lower grade (freshman and sophomore) students.

The role of the internet in academic research and learning of students was conducted by Oberiri \& Iyendo (2018) in three selected universities within North-Eastern Nigeria. The students perceived that the lack of digital readiness among their staff and institution, the absence of electronic library for easy accessibility to journals from the scientific database, and inefficient cybercafé and internet facility within their university settings were the main issues discouraging the utilization of the internet within their institutions. Yet, they still strive to find ways through self-organization, resilience, and resourcefulness to make use of the internet to facilitate their studies. Most of them stated that they depended on their smartphone/handsets to access the internet through subscription from other internet providers and have become overly reliant on Google, Yahoo, and open access e-Journals. Nevertheless, the students believed that the use of the internet enabled them to perform research ahead of time, tackle multiple homework, widen the scope of reading and learning, promote self-learning, encourage, and enhance peer learning as well as ameliorate student's examination preparation.

An exploration of factors influencing self-efficacy in online learning was reviewed by Peechapol, Na-Songkhla, Sujiva, and Luangsodsai (2018) at Chulalongkorn University, Bangkok, Thailand. According to their study, self-efficacy is the key to success in all activities, including online learning. Hence, the understanding of the source of self-efficacy in an online learning context is important. As found in this systematic review, online learning experience and knowledge, feedback and reward, online communication and interactions, social influence, and learner motivation and attitude are factors that influenced learner self-efficacy in the online learning context.

In 2014, an examination of faculty self-efficacy related to online teaching was done by Horvitz, Beach, Anderson, and Xia. They sought to gain an understanding of the challenges professors face as they make the transition to teaching online. Results showed that online teaching self-efficacy was high among the professors surveyed. The perception of student learning was the independent variable with the greatest impact on self-efficacy. Other variables that had a significant relationship with self-efficacy sub-scales were semesters taught online, future interest in teaching online, gender, satisfaction with teaching online, and academic discipline.

\section{Problem Statement and Research Questions}

Exploring the factors influencing the readiness of faculty and students on online teaching and learning is vital if the university attempts to utilize an alternative delivery mode to continue the teaching-learning process, even the absence of face-to-face interactions between teachers and students.

The literature suggests that device access and connectivity, familiarity, and capability in using online materials, preparation, experience with technology, and self-efficacy are constructs that can be investigated if respondent readiness to teach and learn online is to be examined. Hence, this study will explore the following two research questions:

(1). What is the extent of respondent device access and connectivity, familiarity, and capability in using online materials, preparation, experience with technology, and self-efficacy, and readiness to teach and learn online?

(2). Do respondent device access and connectivity, familiarity, and capability in using online materials, preparation, experience with technology, and self-efficacy significantly explain their readiness to teach and learn online?

\section{Research Methods}

\subsection{Research Design}

The present study is quantitative research with descriptive-correlational, particularly explanatory (predictive) as the main method in analyzing the data. It is quantitative as the researcher is detached from participants and strives to be objective and summarizes the results numerically (Lodico, Spaulding, and Voegtle, 2006). It is a prediction since it did not only examine correlations between variables, but also identified one or more variables (device access and connectivity, familiarity and capability 
in using online materials, preparation, experience with technology, and self-efficacy) that can predict changes in another variable measured (readiness).

\subsection{Context and Participants}

The current study was conducted at the Laguna State Polytechnic University, Philippines. The questionnaire was posted, sent via private message, and e-mailed to faculty and students of the university. A sample of 7,553 usable responses was obtained from a variety of senior high school, undergraduate, graduate students, and faculty. The respondents were asked to describe their personal characteristics in terms of campus, sex, and age. They were also asked to respond in reference to Yes-No, 4-point, and 5-point Likert-type scales on the constructs discussed in the instrument sub-section below.

The Santa Cruz-Main Campus registered with the highest number of respondents, with 3,452 (45.70\%). It is followed by San Pablo City Campus (2,478; 32.81\%), Los Banos $(921 ; 12.19 \%)$, and Siniloan (702; 9.29\%). There were more female respondents $(4,392 ; 58.1 \%)$ than male respondents $(3,161 ; 41.9 \%)$. Regarding their age, the majority of the student - respondents who participated were $16-20$ years old $(5,059 ; 70.22 \%)$ while there are 167 (47.99\%) faculty whose ages range from $21-35$ years old. It indicates that this group was outnumbered by digital natives.

\subsection{Research Instrument}

The Faculty and Student Readiness to Teach and Learn Online (FSRTLO) instrument were developed by the authors with reference to the literature (theoretical models and previous research). Research studies (Peechapol, Na-Songkhla, Sujiva, and Luangsodsai 2018; Horvitz, Beach, Anderson, and Xia, 2014; Oberiri \& Iyendo, 2018; Hung, Chou, Chen and Own, 2010; Martin, Budhrani, and Wang, 2019; and Gay, 2016) were reviewed to identify a framework and instrument that can be used to measure faculty readiness to teach online and student preparedness to learn online. This online survey instrument included the following components:

1. Personal Characteristics. It asks the respondent campus location, age, and sex.

2. Device Access and Connectivity. It is an eight-item questionnaire that solicits current respondent status of owning or acquiring gadgets such as smartphones and laptops. It is a 4 - point Likert-type scale, with anchors ranging from 1 (Not Acquired) to 4 (Personally Owned).

3. Exposure with Technology. This is a 16 - item questionnaire that assesses respondent experience with technology. It further describes how often the respondents use different forms of educational technology in the teaching-learning process. It is a 5 point Likert-type scale, with anchors ranging from 1 (Never) to 5 (Always).

4. Familiarity and Capability. A 14 -item questionnaire that evaluates respondent awareness and capacity in using online teaching/learning materials in video format that are available on the internet or worldwide web. It is a 4 - point Likert-type scale, with anchors ranging from 1 (Not Familiar/Not Capable) to 4 (Very Much Familiar/Very Much Capable).

5. Preparation. This three-item question validates respondent attendance to training/ or workshop on online/ distance education or e-learning/teaching platforms. It is an alternate response type of assessment answerable by Yes or No.

6. Self - efficacy. According to Albert Bandura, an influential social cognitive psychologist, self-efficacy is defined as the belief in one's capabilities to organize and execute the courses of action required to manage prospective situations. In this study, it is an item that asks the respondent's personal assessment of their ability to conduct and participate in online teaching and learning. They rated themselves using the scale of one (1, lowest) to ten (10, highest).

7. Readiness. This $10-$ item questionnaire gauges the degree of respondent preparedness, willingness, and motivation to attend in online teaching and learning. It is a 4 - point Likert-type scale, with anchors ranging from 1 (Lack of Readiness) to 4 (Very Much Ready).

The researchers-made online survey instrument was content - validated by experts in the fields of educational management, quality assurance, statistics, and research. It is highly accepted in terms of suitability and appropriateness of items and reported an excellent reliability index of Cronbach $\alpha=0.95$. It was programmed in the google form by the ICT experts in the university, and the extracted data were analyzed using descriptive statistics such as frequency count, percent, and weighted mean. The multiple linear regression using the Enter Method was employed for the inferential analysis of data. 
Table 1. Respondents' Current Status in Terms of Device Access and Connectivity

\begin{tabular}{cccccc}
\hline \multirow{2}{*}{ Device } & \multicolumn{3}{c}{ Students } & \multicolumn{2}{c}{ Faculty } \\
\cline { 2 - 5 } & $\mathbf{f}$ & Description & $\mathbf{f}$ & Description & \\
\hline Smartphone & 6,304 & Personally Owned & 320 & Personally Owned & 3.79 \\
Tablet & 6,351 & Not Acquired/ No Access & 267 & Not Acquired/ No Access & 1.30 \\
Laptop & 3,613 & Not Acquired/ No Access & 274 & Personally Owned & 2.29 \\
Desktop PC & 6,070 & Not Acquired/ No Access & 249 & Not Acquired/ No Access & 1.34 \\
Internet Connection via Stable Provider & 3,739 & Not Acquired/ No Access & 165 & Shared w/Family Member & 2.08 \\
$\begin{array}{c}\text { (e.g., Globe, PLDT, etc.) } \\
\text { Internet Connection via Mobile Data }\end{array}$ & 4,040 & Personally Owned & 265 & Personally Owned & 3.06 \\
\hline
\end{tabular}

\section{Results}

\subsection{On Device Access and Connectivity}

Based on the results in Table 1, both groups of respondents rely heavily on personally owned smartphones and internet connection via mobile data. Half of the student-respondents have no internet connection via the stable provider, while most of the faculty-respondents shared with family members. It seems that the respondents have owned/shared laptops $(\bar{x}=2.29)$ but many of them do not acquire tablet $(\bar{x}=1.30)$ nor desktop personal computer $(\bar{x}=1.34)$.

4.1.1. On access and use of devices to do school work in a day

Table 2. Respondents' Access and Use of Devices to Do School work in a Day

\begin{tabular}{|c|c|c|c|c|c|}
\hline \multirow{2}{*}{ Responses } & \multicolumn{2}{|c|}{ Students } & \multicolumn{2}{|c|}{ Faculty } & \multirow{2}{*}{$\bar{x}$} \\
\hline & $\mathbf{f}$ & $\%$ & f & $\%$ & \\
\hline About 1 to 2 hours & 2823 & 39.2 & 65 & 18.7 & \\
\hline About 3 to 4 hours & 1800 & 25.0 & 92 & 26.4 & \\
\hline Unlimited access & 1531 & 21.2 & 171 & 49.1 & 2.56 \\
\hline $\begin{array}{l}\text { I cannot use the device } \\
\text { for school work }\end{array}$ & 727 & 10.1 & 10 & 2.9 & \\
\hline Other & 324 & 4.5 & 10 & 2.9 & \\
\hline Total & 7,205 & 100.0 & 348 & 100.0 & \\
\hline
\end{tabular}

Almost $85 \%$ of the student - respondents and $95 \%$ of the teacher - respondents said that they have about 1 hour to unlimited access and use of devices in a day. They usually use them for personal, leisure, and educational (content and research work/document creation) purposes. The remaining percentage mentioned that they could not use the device for school work. The mean score of 2.56 suggests that, on average, they have use and access devices in one to two hours a day.

4.1.2. On places one typically goes in accessing the internet

Table 3. Oher Places One Typically Goes in Accessing the Internet (Aside from School and Home)

\begin{tabular}{|c|c|c|c|c|c|}
\hline \multirow{2}{*}{ Responses } & \multicolumn{2}{|c|}{ Students } & \multicolumn{2}{|c|}{ Faculty } & \multirow{2}{*}{$\bar{x}$} \\
\hline & f & $\%$ & f & $\%$ & \\
\hline $\begin{array}{c}\text { Commercial } \\
\text { establishments with } \\
\text { free WIFI connection }\end{array}$ & 991 & 13.8 & 62 & 17.8 & \\
\hline Internet Cafe/Shop & 2584 & 35.9 & 90 & 25.9 & 2.16 \\
\hline None & 3415 & 47.4 & 185 & 53.2 & \\
\hline Other & 215 & 3.0 & 11 & 3.2 & \\
\hline Total & 7,205 & 100.0 & 348 & 100.0 & \\
\hline
\end{tabular}

Half of the respondents reported that they do not go to any place in accessing the internet. Some of them go to internet café/shop while very few subscribe to commercial establishments with free WIFI connection. A lower mean of 2.16 supports the salient finding in Table 1, which emphasizes that they can access the internet using their smartphones and mobile data. 
Table 4. Respondent's Experience with Technology

\begin{tabular}{|c|c|c|c|c|c|}
\hline \multirow{2}{*}{ Device } & \multicolumn{2}{|c|}{ Students } & \multicolumn{2}{|r|}{ Faculty } & \multirow{2}{*}{$\overline{\boldsymbol{x}}$} \\
\hline & f & Description & f & Description & \\
\hline E-mail & 2875 & Rarely & 143 & Occasional & 1.86 \\
\hline Instant Messenger & 2607 & Almost every time & 141 & Always & 3.56 \\
\hline Web Browser & 2383 & Almost every time & 103 & Almost every time & 2.49 \\
\hline Word Processing & 2751 & Occasional & 117 & Always & 2.11 \\
\hline Spreadsheet & 2751 & Rarely & 119 & Occasional & 1.65 \\
\hline Presentation Software & 2612 & Occasional & 108 & Occasional & 1.99 \\
\hline Database Program & 3396 & Never & 125 & Never & 1.48 \\
\hline Web Page Creation Software & 4172 & Never & 193 & Never & 1.38 \\
\hline Image Editing Software & 2974 & Never & 139 & Never & 1.53 \\
\hline Page Layout & 2994 & Never & 120 & Never & 1.54 \\
\hline Adobe Acrobat & 4925 & Never & 147 & Never & 1.32 \\
\hline Digital Video & 1254 & Never & 111 & Never & 1.47 \\
\hline Audio Editing Software & 4592 & Never & 184 & Never & 1.31 \\
\hline IPods & 6119 & Never & 281 & Never & 1.14 \\
\hline Podcasting & 5908 & Never & 278 & Never & 1.16 \\
\hline Text Messaging & 2256 & Occasional & 92 & Always & 2.29 \\
\hline Overall & & & & & 1.77 \\
\hline
\end{tabular}

\subsection{On Experience with Technology}

Table 4 described that the respondents use instant messenger almost every time, if not always, as a form of educational technology in the teaching-learning process $(\bar{x}$ $=3.56$ ). The students rarely/occasionally use the web browser, word processing, spreadsheet, presentation software, e-mail, and text messaging, probably because they seldom need such applications in their studies. On the other hand, faculty - respondents greatly depend on these technological tools to facilitate the teaching-learning process. Generally, the respondents rarely admitted less exposure to these platforms (overall $\bar{x}=1.77$ ).

\subsection{On Familiarity and Capability}

The respondents reported that they were much familiar and very much capable of using e-mail $(\bar{x}=3.22)$, social media applications $(\bar{x}=3.14)$., and text messaging $(\bar{x}=$ 3.48). These platforms are commonly used and accessed online learning materials nowadays because of their user-friendly feature.
With an overall mean of 1.77 , the students and faculty have an opposite level of familiarity and capability in using videos from youtube and ted talk. While the students were much familiar in using videos from youtube, the faculty declared unfamiliarity and incapability in using it. Meanwhile, the reverse is true in using videos from ted talk.

Moreover, both groups of respondents declared quite a familiarity and capability in using the youtube channel. The majority of the respondents admitted that they were familiar but not capable of using Facebook classroom, google classroom, screencastify, loom, flip-grid, screencast-o-matic, and webinar (see Table 5).

\subsection{On Preparation}

It is evident from the results in Table 6 that a great number of students and faculty had not attended training/workshops nor online course during formal education. Most students did not subscribe to online libraries for schoolwork, while almost half of the faculty respondents did (overall $\bar{x}=1.20$ ). 
Table 5. Respondent's Familiarity and Capability in Using Online Teaching/Learning Materials

\begin{tabular}{|c|c|c|c|c|c|c|}
\hline & \multirow{2}{*}{ Online Material } & \multicolumn{2}{|r|}{ Students } & \multicolumn{2}{|r|}{ Faculty } & \multirow{2}{*}{$\overline{\boldsymbol{x}}$} \\
\hline & & f & Description & f & Description & \\
\hline 1. & $\begin{array}{l}\text { Videos from } \\
\text { YouTube }\end{array}$ & 2710 & $\begin{array}{c}\text { Much Familiar/Much } \\
\text { Capable }\end{array}$ & 182 & Not Familiar/ Not Capable & 3.06 \\
\hline 2. & $\begin{array}{l}\text { Videos from Ted } \\
\text { Talk }\end{array}$ & 2607 & $\begin{array}{l}\text { Not Familiar/Not } \\
\text { Capable }\end{array}$ & 127 & Much Familiar/ Much Capable & 1.52 \\
\hline 3. & Facebook Classroom & 2402 & Familiar/ Not Capable & 111 & Much Familiar/Much Capable & 2.19 \\
\hline 4. & Google Classroom & 2434 & Familiar/ Not Capable & 125 & Familiar/Not Capable & 2.11 \\
\hline 5. & ZOOM & 4390 & $\begin{array}{l}\text { Not Familiar/Not } \\
\text { Capable }\end{array}$ & 127 & Familiar/ Not Capable & 1.59 \\
\hline 6. & YouTube Channel & 2608 & Familiar/Not Capable & 137 & Familiar/Not Capable & 2.62 \\
\hline 7. & Screencastify & 5789 & $\begin{array}{l}\text { Not Familiar/Not } \\
\text { Capable }\end{array}$ & 255 & Not Familiar/ Not Capable & 1.27 \\
\hline 8. & Loom & 6349 & $\begin{array}{l}\text { Not Familiar/Not } \\
\text { Capable }\end{array}$ & 289 & Not Familiar/ Not Capable & 1.15 \\
\hline 9. & Flipgrid & 6392 & $\begin{array}{l}\text { Not Familiar/Not } \\
\quad \text { Capable }\end{array}$ & 288 & Not Familiar/ Not Capable & 1.14 \\
\hline 10. & Screencast-o-matic & 2994 & $\begin{array}{l}\text { Not Familiar/Not } \\
\text { Capable }\end{array}$ & 288 & Not Familiar/ Not Capable & 1.16 \\
\hline 11. & $\begin{array}{l}\text { E-mail (e.g., Gmail, } \\
\text { yahoo, msn, etc.) }\end{array}$ & 2850 & $\begin{array}{c}\text { Much Familiar/Much } \\
\text { Capable }\end{array}$ & 147 & $\begin{array}{l}\text { Very much familiar/Very Much } \\
\text { Capable }\end{array}$ & 3.22 \\
\hline 12. & $\begin{array}{l}\text { Social Media (e.g., } \\
\text { Facebook, Twitter, } \\
\text { Instagram, etc.) }\end{array}$ & 4199 & $\begin{array}{l}\text { Very much familiar/ } \\
\text { Very Much Capable }\end{array}$ & 221 & $\begin{array}{l}\text { Very much familiar/Very Much } \\
\text { Capable }\end{array}$ & 3.14 \\
\hline 13. & $\begin{array}{l}\text { Instant Messaging } \\
\text { (e.g., Text } \\
\text { Messaging, Viber, } \\
\text { Messenger, Line, } \\
\text { WeChat, WhatsApp, } \\
\text { etc.) }\end{array}$ & 3000 & $\begin{array}{l}\text { Very much familiar/ } \\
\text { Very Much Capable }\end{array}$ & 210 & $\begin{array}{l}\text { Very much familiar/Very Much } \\
\text { Capable }\end{array}$ & 3.48 \\
\hline 14. & Webinar & 5840 & $\begin{array}{c}\text { Not Familiar/Not } \\
\text { Capable }\end{array}$ & 138 & Not Familiar/ Not Capable & 1.32 \\
\hline & Overall & & & & & 2.07 \\
\hline
\end{tabular}

Table 6. Respondent's Preparation in Terms of Attendance to Training/Workshops and Subscription to Online Library

\begin{tabular}{|c|c|c|c|c|c|}
\hline \multirow[b]{2}{*}{ Preparation } & \multicolumn{2}{|c|}{ Students } & \multicolumn{2}{|c|}{ Faculty } & \multirow[b]{2}{*}{$\bar{x}$} \\
\hline & $\begin{array}{l}\text { Yes } \\
\text { (f) }\end{array}$ & $\begin{array}{l}\text { No } \\
\text { (f) }\end{array}$ & $\begin{array}{c}\text { Yes } \\
\text { (f) }\end{array}$ & $\begin{array}{l}\text { No } \\
\text { (f) }\end{array}$ & \\
\hline $\begin{array}{c}\text { Attendance to training/workshop in online } \\
\text { education }\end{array}$ & 600 & 6605 & 111 & 237 & 1.09 \\
\hline $\begin{array}{l}\text { Attendance to an online course during formal } \\
\text { education }\end{array}$ & 561 & 6644 & 77 & 271 & 1.08 \\
\hline Online subscriptions & 2986 & 4219 & 173 & 175 & 1.42 \\
\hline Overall & & & & & 1.20 \\
\hline
\end{tabular}

\subsection{On Self-efficacy}

Table 7. Respondent's Self- efficacy to Participate in Online Teaching and Learning

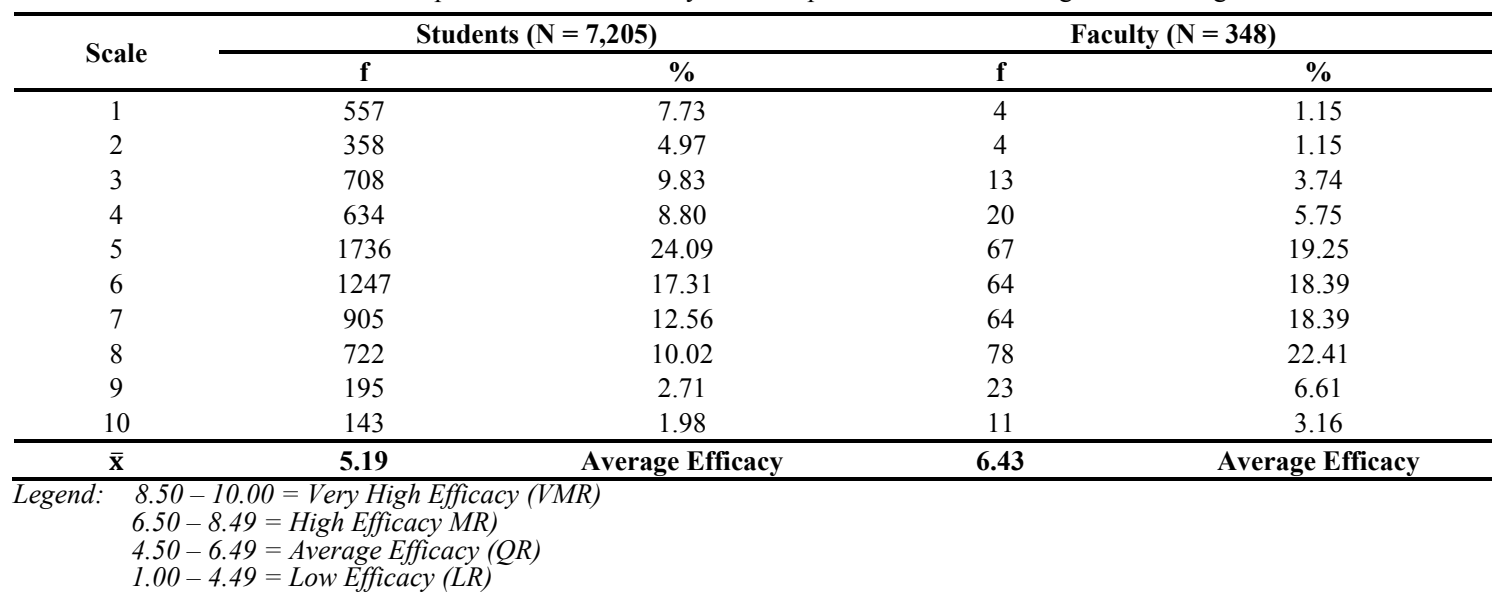


If the respondent's self-assessment will be considered, it is very evident that the students $(\bar{x}=5.19)$ and faculty $(\bar{x}=$ 6.43) exposed an "average level of self-efficacy" for online teaching and learning. It means that they are quite capable of adopting online learning in place of face-to-face classes. Although e-learning is an impressive way of flexible learning in higher education, it greatly requires substantial capacity among members of the academic community (see Table 7).

Generally, the students and faculty were quite ready to participate in online teaching and learning (overall $\bar{x}=$ 2.19). It can be gleaned from the data in Table 8 that the students and faculty unanimously regarded the statement "Having computers and stable internet access intended for online classes" as the least among the ten indicators $(\bar{x}=$ 1.80 ). Since teaching and learning in the online modality is different from teaching and learning in the classroom, the faculty and student attitudes towards technology and teaching and learning were apparently fluctuating.

\subsection{On Readiness}

Table 8. Respondents' Readiness on the Conduct of Online Teaching/Participation in Online Learning

\begin{tabular}{llcl}
\hline \multicolumn{1}{c}{ Indicative Statement } & $\overline{\boldsymbol{x}}$ & Description \\
\hline 1. & $\begin{array}{l}\text { The familiarity of e-learning and its } \\
\text { advantages and disadvantages. }\end{array}$ & 2.19 & Quite Ready \\
2. $\begin{array}{l}\text { My knowledge and skills required in } \\
\text { conducting/participating in online } \\
\text { classes such as search skills. }\end{array}$ & 2.27 & Quite Ready \\
3. $\begin{array}{l}\text { Having computers and stable internet } \\
\text { access intended for online classes. }\end{array}$ & 1.80 & Quite Ready \\
4. $\begin{array}{l}\text { Using devices (smartphones, laptops, } \\
\text { tablets) for my online classes with } \\
\text { effectiveness. }\end{array}$ & 2.34 & Quite Ready \\
5. $\begin{array}{l}\text { Using any of the available learning } \\
\text { management systems or resources } \\
\text { effectively. }\end{array}$ & 2.12 & Quite Ready \\
6. $\begin{array}{l}\text { Motivating myself to utilize features } \\
\text { of an online learning environment. } \\
\text { Managing my time in the } \\
\text { conduct/participation of/on online } \\
\text { classes. }\end{array}$ & 2.26 & Quite Ready \\
8. $\begin{array}{l}\text { Valuing and practicing social } \\
\text { responsibility and legal use of ICT } \\
\text { tools and resources. }\end{array}$ & 2.18 & Quite Ready \\
9reparing/submitting \\
requirements/outputs.
\end{tabular}

Legend: $\quad 3.50-4.00=$ Very Much Ready (VMR); 2.50-3.49= Much Ready (MR); $1.50-2.49=$ Quite Ready $(Q R) ; 1.00-1.49=$ Lack of Readiness (LR)

\subsection{On the Test of Significant Prediction}

Multiple linear regression was calculated to predict the respondent readiness based on device access and connectivity, exposure with technology, familiarity and capability, preparation, and self-efficacy. A significant regression equation was found $(\mathrm{F}(5,7547)=2433.92, p$ $<.001$ ), with an $\mathrm{R}^{2}=$ of .786 . Participant's predicted readiness $(\mathrm{R})$ is equal to

$$
\begin{gathered}
\mathrm{R}=-.423+.484 \mathrm{FC}+.240 \mathrm{P}+.162 \mathrm{DAC}+.147 \mathrm{SE} \\
+.106 \mathrm{ET} \text { where }
\end{gathered}
$$

$\mathrm{FC}=$ Familiarity and Capability score, $\mathrm{P}=$ Preparation score, $\mathrm{DAC}=$ Device and Access Connectivity, $\mathrm{SE}=$ Self-efficacy score, and ET = Experience with Technology score.

The equation tells that for every one (1) point increase in participant readiness on online teaching and learning, the model predicts .484 points increase in familiarity and capability holding the other factors constant. Moreover, for every one (1) point increase in participant readiness on online teaching and learning, the model predicts .240 points increase in their preparation points, holding the other factors fixed. The model also predicts that for every one (1) point increase in participant readiness on online teaching and learning, their device and access connectivity score will increase by .162, keeping the other predictor variables constant. Furthermore, an increase of .147 points on participant self-efficacy will happen for every one (1) point increase in participant readiness on online teaching and learning, keeping the other factors fixed. Finally, the model explains that for every one (1) point increase in participant readiness on online teaching and learning, their experience with technology score will increase by .106 points holding the other factors constant.

The model further revealed that $67.1 \%$ of the variation on participant's readiness score is significantly explained by their familiarity and capability, preparation, device and access connectivity, self-efficacy, and experience with technology.

Table 9. Test of Significant Prediction among Factors Influencing Respondents' Readiness on the Conduct of Online Teaching/Participation in Online

\begin{tabular}{|c|c|c|c|c|c|}
\hline \multirow{2}{*}{ Predictors/Factors } & \multicolumn{2}{|c|}{ Unstandardized Coefficients } & \multirow{2}{*}{$\begin{array}{c}\text { Standardized Coefficients } \\
\beta\end{array}$} & \multirow{2}{*}{$\mathbf{t}$} & \multirow{2}{*}{ Sig. } \\
\hline & B & Std. Error & & & \\
\hline (Constant) & -.423 & .032 & & -13.190 & .000 \\
\hline Familiarity and Capability & .484 & .015 & .297 & 32.221 & .000 \\
\hline Preparation & .240 & .022 & .084 & 10.788 & .000 \\
\hline Device Access and Connectivity & .162 & .012 & .116 & 13.536 & .000 \\
\hline Self-efficacy & .147 & .003 & .452 & 54.201 & 0.000 \\
\hline Experience with Technology & .106 & .012 & .076 & 8.965 & .000 \\
\hline$N=7,553 \quad R^{2}=.786$ & $R^{2}=.67$ & $F(5,7547)$ & $3.92 ; p<.01$ & & \\
\hline
\end{tabular}
Learning 


\section{Discussion}

Technology ushers in fundamental structural changes that can be integral to support both teaching and learning. Digital learning tools, such as computers and handheld devices, and an internet connection, support learning 24 hours a day, seven days a week, builds $21^{\text {st }}$-century skills, increases student engagement and motivation, and accelerates learning.

As considerable numbers of faculty are suddenly required to move their courses to a completely online environment, it is important to take stock of the devices to which they have access and how they have access (Brooks and Grajek, 2020). If online teaching and learning are pushed through, there are available device access and connectivity, if not owned by all, but at least acquired/accessed by great majority.

However, a sizeable percentage of faculty and students have no access to laptops or desktops, which suggests that there are huge gaps between the work faculty and students that are being asked to do and the tools that are being provided to conduct that work. The institution needs to consider how faculty and student will access devices to teach and learn their courses online. Using a personally owned device to access the LMS or online storage to deliver the course online presents little risk.

When online teaching and learning is designed, it is also important to cover participant familiarity and capability in using technology and their preparation to participate in this alternative delivery mode. Action plan or guidelines about how teaching and learning work in online environments may be in place. The institution may also provide expanded support and additional channels of support to help faculty and students.

\section{Conclusions}

As a Higher Education Institution (HEI), the Laguna State Polytechnic University (LSPU) joins the Philippine government with all its actions deemed pertinent to this cause, which includes the launching of different initiatives to take care of its students and employees, and the community.

Since the experience that we have is unprecedented, the teaching-learning that is taking place is remote teaching or a modern term as "pandemic pedagogy."

The university may utilize an alternative form of delivery mode or flexible learning to continue the teaching-learning process, even the absence of face-to-face interactions between teachers and students.

Online teaching/education becomes the trend for borderless education and globalization. Although to some modern universities, online teaching/education as a medium is inferior.

However, online education, if well-designed, could just be as effective as face-to-face instruction with an emphasis on the design of the learning experience, the quality of the content, and the engagement of learners.

\section{Recommendations}

In the context of delivering high-quality remote education, the following may be considered:

1. Provide technical support to the needy students in terms of gadget/laptop/ cellphone/ and pocket wifi to have easy access to the internet connection.

2. A sound policy on the use of the flexible learning mode using the internet must be thoroughly discussed.

3. The university may hasten the computerization system to facilitate the online delivery of service.

4. The university and in a wider scope, the CHED may conduct series of training for teachers as a capacity building to equip them with knowledge and competencies on the use of flexible learning or blended learning on the following:

a. Guidelines on the use of an online system of teaching and learning

b. Constructive alignment of all the elements in an Obedized education in terms of curriculum contents, learning activities, and assessment procedures.

c. Principles in the execution of online teaching or video conferencing or creation of a virtual classroom

d. Preparation of online learning materials

e. Monitoring of the teachers performing the job, students are attending the classes and the assurance that the learning objectives are carried out.

f. Policy guidelines on the evaluation of the efficiency and effectiveness of the online system for teaching and learning

5. Communication must be observed with frequency and honesty with the students, other colleagues, and university officials of the purpose/intentions of the delivery mode.

6. Establish short- and long-term priorities and steps to be accomplished.

7. School leaders and teachers need to be flexible and very creative in establishing policies and practices to be effective.

\section{REFERENCES}

[1] Aliazas, J., \& Callo, E. (2019). Educational Technology for Teaching \& Learning and Students' Proficiency Skills in Science and Technology. Institutional Paper, College of Teacher Education, Laguna State Polytechnic 
University-San Pablo City.

[2] Bates, T. The 2017 national survey of online learning in Canadian post-secondary education: methodology and results. Int J Educ Technol High Educ 15, 29 (2018). https://doi.org/10.1186/s41239-018-0112-3

[3] Brooks, C. \& Grajek, S. (2020). Faculty Readiness to Begin Fully Remote Teaching. https://er.educause.edu/blogs/2020 /3/faculty-readiness-to-begin-fully-remote-teaching

[4] Callo, E., \& Baguna, A. (2017). Designed Facebook Classroom: Innovation for Improving Teaching-Learning Practices in Computer Science Subject. International Journal of Advanced Research, 5(6), 2026-2038. doi:10.21474/ijar $01 / 4637$

[5] Emmanuel, W. (2020, April 23). Online learning in the time of COVID19: A Computer Science Educator's Point of View. https://arete.ateneo.edu/connect/online-learning-in-the-time -of-covid19-a-computer-science-educators-point-ofview?fb clid=IwAR1 rqErdoDqS52tmXIroUfqmK22cyQoz4xq-4kG hBbzL5wp8vCiczqCnqX4

[6] Gay, G. (2016). An assessment of online instructor e-learning readiness before, during, and after course delivery.

https://link.springer.com/article/10.1007/s12528-016-9115Z

[7] Hung, M., Chou, C., Chen, C., \& Own, Z. (2010). Learner readiness for online learning: Scale development and student perceptions. Elsevier. 3 (55). https://www.sciencedi rect.com/science/article/abs/pii/S0360131510001260?via\% 3Dihub

[8] Horbitz, B., Beach, A., Anderson, M., \& Xia, J. (2014). Examination of Faculty Self-efficacy Related to Online Teaching. Innovative Higher Education. https://www.resear chgate.net/publication/269468181

[9] Lodico, N., Spaulding, D., \&Voegtle, K. (2006). Methods of Educational Research. John Wiley \& Sons, Inc.
[10] Martin, F. Budhrani, K., and Wang, C. (2019). Examining Faculty Perception of Their Readiness to Teach Online. Online Learning Journal, 23 (2019) https://files.eric.ed.gov/fulltext/EJ1228799.pdf

[11] Milman, N. (2020, March 30). This is an Emergency, not just an Online Teaching. Education Week. https://www.edweek.org/ew/articles/2020/03/30/this-is-eme rgency-remote-teaching-not-just.html

[12] Naldoza, N. (2020, April). Online Teaching and Learning Preparedness Survey. https://docs.google.com/forms/d/e/1F AIpQLSfU_i57h19jgASOby9PeWZtrpNeYwFIc8ApdBkh FAcOxj5euA/viewform

[13] Oberiri, A. \& Iyendo, T. (2018). University students' usage of the internet resources for research and learning: forms of access and perceptions of utility. https://www.cell.com/heliy on/fulltext/S2405-8440(18)34122-7? returnURL $=$ https\%3 A\% 2 F\%2Flinkinghub.elsevier.com\% $\%$ Fretrieve $\% 2 F$ pii $\% 2 F$ S2405844018341227\%3Fshowall\%3Dtrue\#articleInformat ion

[14] Peechapol, C. Na-Songkhla, J., Sujiva, S., \& Luangsodsai, A. (2018). An Exploration of Factors Influencing Self-Efficacy in Online Learning: A Systematic Review. International Journal of Emerging Technologies in Learning. https://online-journals.org/index.php/i-jet/article/view/8351

[15] Rasouli, A., Rahbania, Z., \& Mohammad, A. (2016). Students' Readiness for E-learning Application in Higher Education. Malaysian Online Journal of Educational Technology. 3 (4).

[16] Shailendra, P., Prageet A., Parul G., Diptiranjan, M., Ratri, P., Rosner, R., \& Sindhi, S. (2018) Online Education: Worldwide Status, Challenges, Trends, and Implications, Journal of Global Information Technology Management, 21:4, 233-241, DOI: 10.1080/1097198X.2018.1542262

[17] Yazon A., Manaig, K., Buama, C. \& Tesoro, J. Digital Literacy, Digital Competence and Research Productivity of Educators. Universal Journal of Educational Research 7.8 (2019) 1734 - 1743. doi: 10.13189/ujer.2019.070812. 